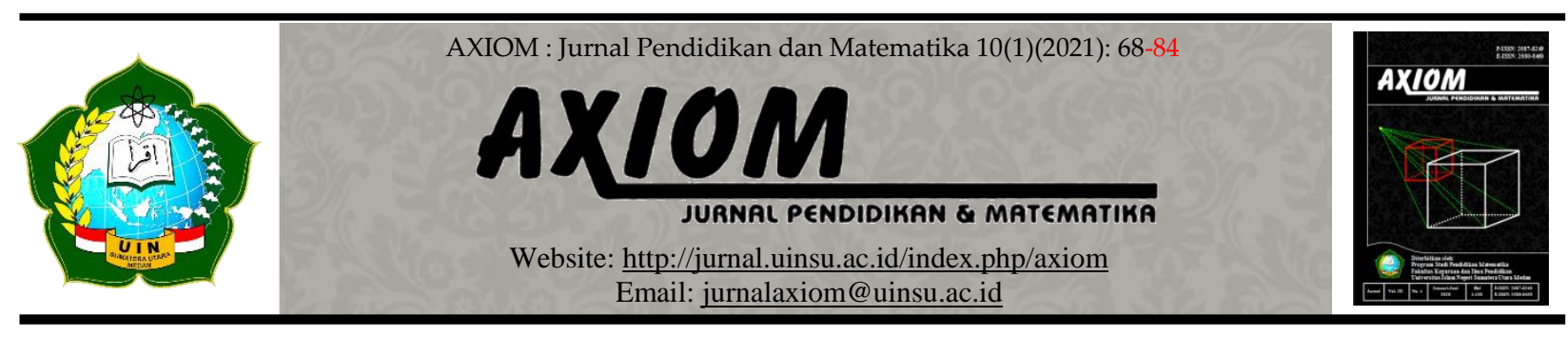

\title{
KEMAMPUAN KOMUNIKASI MATEMATIS DITINJAU DARI KETERLIBATAN SISWA MELALUI PENDEKATAN REALISTIC MATHEMATICS EDUCATION (RME)
}

Oleh:

\author{
Lisa Ramadhani ${ }^{1}$, Rahmah Johar ${ }^{2}$, Bansu Irianto Ansari ${ }^{3}$ \\ ${ }^{1,2}$ Magister Pendidikan Matematika, FKIP, Universitas Syiah Kuala \\ ${ }^{3}$ Magister Pendidikan Matematika, FKIP Universitas Serambi Mekkah \\ E-mail: $\underline{1 \text { lisa_ramadhani03@yahoo.com, }}{ }^{2}$ rahmah.johar@unsyiah.ac.id , \\ bansu_ansari@yahoo.co.id
}

doi : 10.30821/axiom.v10i1.8825

\begin{abstract}
Abstrak:
Tujuan penelitian ini adalah untuk mendeskripsikan kemampuan komunikasi matematis ditinjau dari keterlibatan siswa pada materi segiempat melalui pendekatan RME. Penelitian ini merupakan penelitian kualitatif. Subjek dalam penelitian ini adalah 6 orang siswa kelas VII-1 SMP IT ALAzhar Banda Aceh yang dipilih berdasarkan banyaknya indikator keterlibatan yang dipenuhi. Teknik pengumpulan data yang digunakan dalam penelitian ini yaitu observasi keterlibatan siswa dan tes kemampuan komunikasi matematis yang telah divalidasi. Data dianalisis dengan melakukan reduksi data, penyajian data dan penarikan kesimpulan. Berdasarkan hasil penelitian maka dapat disimpulkan bahwa kemampuan komunikasi matematis ditinjau dari keterlibatan siswa melalui pendekatan RME sudah baik. Hal ini terlihat dari hasil pencapaian kemampuan komunikasi matematis yang ditinjau dari keterlibatan siswa terhadap 4 orang subjek sudah berada pada katagori baik, artinya subjek telah memperoleh pembelajaran dengan baik karena pada saat pembelajaran subjek terlibat aktif serta memiliki kemampuan komunikasi matematis yang baik. Penggunaan pendekatan RME juga membangkitkan semangat siswa agar terlibat dalam pembelajaran serta memperoleh kemampuan komunikasi matematis yang baik. Namun, terdapat dua subjek dengan keterlibatan serta kemampuan komunikasi matematis dalam pembelajaran yang masih rendah.
\end{abstract}

Kata Kunci:

Kemampuan Komunikasi Matematis, Keterlibatan Siswa, Pendekatan RME

\section{Abstract:}

The purpose of this research was to describe students' mathematical communication skills. They were observed based on students' involvement in studying quadrilateral through the Realistic Mathematics Education (RME). This research was a qualitative research. The subjects in this research were 6 students of class VII-1 Islamic Junior High School AL-Azhar Banda Aceh who were selected based on the number of certain indicators that were fulfilled. The data collection techniques used in this research were observation of students' involvement, and tests of mathematical communication skills. The instruments for data collection had been previously validated. The data were analyzed by doing data reduction, data presentation, and drawing conclusions. Based on the research results, it could be concluded that students' mathematical communication skills observed based on students' involvement in the learning quadrilateral 
through the RME approach were good. This could be seen from the achievement of 4 students who accomplished good chategory in mathematical communication skills. This showed that the subjects had learned well because at the time of learning, the students actively involved and accomplished good mathematical communication skills. Thus, the use of the RME approach also aroused students' enthusiasm to be involved in learning and acquired good mathematical communication skills. However, there were still two subjects with low involvement and mathematical communication skills.

\section{Keywords:}

Mathematical Communication Skills, Students' Involvement, RME Approach

\section{A. Pendahuluan}

Pembelajaran matematika merupakan cara berpikir dan bernalar yang digunakan untuk memecahkan berbagai jenis persoalan dalam keseharian. Pembelajaran matematika bertujuan untuk melatih cara berpikir dan bernalar, mengembangkan aktivitas kreatif, mengembangkan kemampuan memecahkan masalah, mengembangkan kemampuan menyampaikan informasi atau mengkomunikasikan gagasan (UU RI No. 20 Tahun 2003). Pembelajaran harus dapat membantu siswa mengkomunikasikan ide matematika melalui lima aspek komunikasi yaitu representing, listening, reading, discussing dan writing (Baroody, 1993: 107). Secara umum komunikasi dapat diartikan sebagai suatu peristiwa saling menyampaikan pesan yang berlangsung dalam suatu komunitas dan konteks budaya (Ansari, 2016: 11). Kemampuan komunikasi merupakan suatu bagian yang esensial dari matematika dan pembelajaran matematika. Menurut Afgani dan Sutawidjaja (2011: 4.15) komunikasi matematis merupakan suatu kemampuan siswa dalam menulis, membaca, menyimak, menelaah, menginterpretasikan dan mengevaluasi ide, simbol, istilah serta informasi yang berkaitan dengan matematika. Komunikasi matematika adalah kemampuan siswa dalam menjelaskan suatu algoritma dengan cara unik untuk memecahkan suatu masalah, kemampuan sisa mengkonstruksikan dan menjelaskan sajian fenomena dunia nyata secara grafis, kata-kata/kalimat, persamaan, tabel dan sajian secara fisik atau kemampuan siswa memberikan dugaan tentang gambar-gambar, (NCTM, 2000: 60). Kemampuan Komunikasi matematis dapat diartikan sebagai suatu peristiwa dialog atau saling hubungan yang terjadi di lingkungan kelas, dimana terjadi pengalihan pesan dan pesan yang dialihkan berisikan tentang materi matematika yang dipelajari siswa, misalnya berupa konsep, rumus, atau strategi penyelesaian suatu masalah (Susanto 2013: 213). Dengan demikian dapat disimpulkan melalui komunikasi siswa mampu menyampaikan ide yang dimilikinya kepada siswa lainnya. Melalui komunikasi siswa dapat menjelaskan proses berfikir kepada siswa lain baik secara lisan maupun tulisan. Indikator kemampuan komunikasi matematis terdiri dari 1) mengekspresikan ide-ide matematika melalui lisan, tertulis dan mendemonstrasikan serta menggambarkan secara visual, 2) kemampuan memahami, menginterpretasikan, dan mengevaluasikan ide-ide matematika baik secara lisan maupun dalam bentuk visual lainnya; 3) kemampuan dalam menggunakan istilahistilah, notasi-notasi matematika dan strukturnya untuk menyajikan ide, menggambarkan hubungan dan model situasi (NCTM, 2000: 214). Sedangkan Sumarmo (Afgani \& Sutawidjaja, 2011: 4.16) terdapat juga beberapa indikator yang dapat mengukur kemampuan komunikasi matematis siswa yaitu: a) menghubungkan benda nyata, gambar dan diagram ke dalam ide matematika, b) menjelaskan ide, situasi, dan relasi matematika baik secara lisan maupun tulisan dengan benda nyata, gambar, grafik atau bentuk aljabar, c) Menyatakan peristiwa sehari-hari dalam bahasa atau simbol matematika, d) Mendengar, mendiskusi dan menulis tentang matematika, e) Membaca presentasi matematika tertulis dan menyusun pertanyaan yang relevan f) Membuat konjektur, menyusun argumen, merumuskan definisi, dan generalisasi. Berdasarkan indikator yang dikemukakan oleh beberapa ahli di atas, adapun indikator kemampuan komunikasi dalam penelitian ini adalah menghubungkan benda nyata, gambar ke dalam ide matematika, menjelaskan ide dengan mengkonstruk model konseptual seperti gambar, atau bentuk aljabar, menyatakan peristiwa sehari-hari dalam bahasa atau simbol matematika (membuat model). 
Keterlibatan siswa dalam belajar meningkat ketika siswa mampu mengomunikasikan pemahaman mereka kepada siswa lainnya melalui kegiatan kelompok melalui diskusi (Yackel, Cobb \& Wood, 1991: 394). Keterlibatan siswa dalam pendidikan dapat berupa tingkat perhatian, keingintahuan, minat, optimisme, dan semangat yang ditunjukkan siswa ketika mereka sedang belajar (Yuhaniz, Samsudin, Ismail, \& Zaki, 2018: 217). Pembelajaran matematika tidak dapat terjadi tanpa ada keterlibatan dalam proses pembelajaran (Watson, 2007: 8). Terdapat beberapa komponen keterlibatan siswa yang dikemukakan oleh Bodovski dan Farkas (2007: 118) diantaranya: 1) kebiasaan yang dilakukan yang berkaitan dengan pembelajaran (perhatian dan pemecahan masalah); 2) perilaku kognitif (perhatian aktif, menyelesaikan pekerjaan, mengikuti kelas yang menantang); 3) emosi, yang meliputi antusiasme dan minat. Sehingga keterlibatan akan muncul ketika siswa ikut berpartisipasi dalam proses belajar mengajar.

Kenyataan menunjukkan bahwa keterlibatan dan respon siswa terhadap soal-soal komunikasi matematis masih rendah, disebabkan karena bentuk soal tersebut belum pernah dipelajari sehingga siswa sulit untuk menyelesaikan soal tersebut (Purniati, 2003: 3). Siswa yang sudah pandai mengerjakan soal belum tentu bisa mengomunikasikannya. Berdasarkan studi pendahuluan dengan salah seorang guru SMP IT Al-Azhar Banda Aceh bahwa, komunikasi matematis siswa berbeda-beda. Siswa belum optimal dalam menyelesaikan soal-soal kemampuan komunikasi matematis.

Proses pembelajaran yang diterapkan guru pada saat mengajar berpengaruh pada keterlibatan matematika siswa. Guru dengan proses mengajar yang menjelaskan secara langsung cenderung membatasi keterlibatan siswa sedangkan guru dengan proses mengajar yang berfokus pada kegiatan akan mendorong keterlibatan siswa selama pembelajaran (Patahuddin, Lowrie, \& Puteri, 2017: 1). Oleh karena itu, guru perlu melibatkan siswa dalam setiap proses pembelajaran sehingga siswa memiliki keterlibatan aktif selama pembelajaran berlangsung.

Guru dapat mengembangkan kemampuan komunikasi matematis siswa dengan memilih pendekatan yang berhubungan dengan kehidupan nyata yang berdampak pada keterlibatan siswa dalam pembelajaran. Salah satunya yaitu pendekatan RME. RME adalah suatu pendekatan yang berasumsi pembelajaran perlu ada pengaitan antara matematika dengan realitas yang ada dan dapat dijumpai dalam kehidupan sehari-hari (Gravermeijer, 1994: 97). Mengaitkan pengalaman kehidupan nyata siswa dengan ide-ide matematika dalam pembelajaran di kelas penting dilakukan agar pembelajaran dapat bermakna (Soedjadi dkk, 2010). Terdapat beberapa karakteristik RME yaitu penggunaan konteks yang nyata di awal pembelajaran, penggunaan model penyelesaian yang dibangun oleh siswa, pemanfaatan hasil kontribusi siswa, interaktivitas, dan keterkaitan. (Gravemeijer, 1994: 100). Adapun hubungan RME yang berkaitan dengan keterlibatan siswa yaitu pengunaan konteks dan interaktivitas. Melalui penggunaan konteks diawal pembelajaran juga dapat meningkatkan motivasi serta keterkaitan siswa dalam belajar matematika dan melalui interaktivitas proses belajar seseorang bukan hanya untuk individu saja melainkan juga proses belajar siswa akan menjadi lebih singkat dan bermakna ketika siswa saling mengkomunikasikan hasil kerja dan gagasan mereka. Jika pembelajaran yang diajarkan berkaitan dengan kehidupan nyata maka akan mudah untuk dipahami dan dimengerti oleh siswa. Selain itu karakteristik dan prinsip yang dimiliki RME dapat meningkatkan komunikasi matematis siswa. Siswa belajar dari suatu masalah kontekstual yang berdekatan dengan kehidupan sehari-hari sehingga dapat memunculkan suatu konsep matematika. Siswa mampu mengembangkan model-model matematika sendiri menuju matematika yang lebih formal dari masalah kontekstual yang diberikan. Melalui model matematisasi menjadi model of untuk membentuk pengetahuan informal serta model for untuk pengetahuan formal. Dalam diskusi kelompok siswa akan memberikan pendapat terhadap model yang telah mereka temukan, sehingga terbentuk suatu interaktivitas antara mereka sehingga siswa akan belajar berkomunikasi.

Melalui penggunaan konteks yang nyata, siswa tidak hanya diharapkan menemukan jawaban akhir dari permasalahan yang diberikan, tetapi juga diarahkan untuk mengembangkan berbagai strategi penyelesaian masalah, sehingga siswa harus terlibat saat menyelesaikan 
permasalahan yang diberikan. Masalah kontekstual yang diberikan merupakan suatu proses untuk mendukung pengetahuan siswa (Johar, Patahuddin \& Widjaja, 2017: 124) sehingga pembelajaran matematika dengan pendekatan RME lebih baik dalam meningkatan kemampuan komunikasi matematis siswa SMP (Veralita, Rohaeti, \& Purwasih, 2018: 122). Prestasi akademik siswa yang diajar sesuai dengan RME lebih tinggi dari pada siswa yang diajar dengan pembelajaran biasa. Hal ini dikarenakan RME yang bersifat alami sehingga siswa terlibat untuk menyelesaikan suatu masalah, memfasilitasi perolehan pengetahuan matematika dan mendorong siswa untuk menjadi kreatif (Ozkaya \& Karaca, 2017: 193). Namun demikian keterlibatan kognitif, afektif atau perilaku dalam pembelajaran matematika antara para siswa masih perlu perbaikan agar membantu meningkatkan kemampuan komunikasi siswa (Salim \& Ayub, 2017: 4).

Patahuddin, Puteri, Lawrie at all (2017: 124) melakukan penelitian mengenai keterlibatan matematika siswa yang diajarkan oleh 2 orang guru yang berbeda adapun hasil penelitian tersebut ditemukan bahwa proses pembelajaran yang diterapkan guru pada saat mengajar berpengaruh pada keterlibatan matematika siswa, guru dengan proses mengajar yang menjelaskan secara langsung cenderung membatasi keterlibatan siswa sedangkan guru dengan proses mengajar yang berfokus pada kegiatan akan mendorong keterlibatan siswa selama pembelajaran. Zakaria dan Syamaun (2017: 32) menjelaskan bahwa pendekatan RME mendorong siswa untuk berpartisipasi aktif dalam pembelajaran matematika. Oleh karena itu, diperlukan keseriusan dalam kemampuan komunikasi matematis dan pemilihan pendekatan pembelajaran yang akan berdampak pada hasil belajar. Untuk menghadapi masalah kontekstual yang lebih luas dan kompleks, siswa harus menuliskan hasil pemikirannya sebelum dikomunikasikan dan didiskusikan lebih lanjut. Bila hal ini dilaksanakan dengan baik, akan terlihat bahwa penciptaan komunitas matematika di kelas akan terakomodasi. Aktivitas siswa perlu dikondisikan agar mereka dapat berinteraksi sesamanya, diskusi, negosiasi, dan kolaborasi (Umar, 2012: 6). Berdasarkan observasi peneliti dan wawancara dengan guru matematika di SMP IT Al-Azhar Banda Aceh apabila siswa diberikan soal dalam bentuk cerita mengenai materi segiempat siswa tidak dapat mengunakan bahasa matematika untuk mengungkapkan ide matematika dengan tepat. Siswa lebih senang bertanya kepada temannya jika ada yang kurang dimengerti dari pada bertanya kepada guru. Sehingga keterlibatan siswa ketika pembelajaran tidak optimal. Perbedaan penelitian ini dengan beberapa penelitian di atas yaitu belum ada penelitian yang mengkaji tentang keterlibatan siswa selama pembelajaran dengan menerapkan pendekatan RME yang berdampak pada kemampuan komunikasi matematis siswa.

Berdasarkan uraian yang telah dikemukakan maka penliti ingin melihat bagaimana kemampuan komunikasi matematis siswa ditinjau dari keterlibatan siswa (student engagement) melalui pendekatan Realistic Mathematics Education (RME)?

\section{B. Kajian Teoritis}

\section{Kemampuan Komunikasi Matematis}

Komunikasi matematika adalah kemampuan siswa dalam menjelaskan suatu algoritma dengan cara unik untuk memecahkan suatu masalah, kemampuan sisa mengkonstruksikan dan menjelaskan sajian fenomena dunia nyata secara grafis, kata-kata/kalimat, persamaan, tabel dan sajian secara fisik atau kemampuan siswa memberikan dugaan tentang gambar-gambar (NCTM, 2000: 214). Komunikasi matematika terdiri dari, komunikasi lisan (talking) dan komunikasi tulisan (writing). Komunikasi lisan seperti mendengar, membaca, menjelaskan dan berbagi. Sedangkan komunikasi tulisan seperti mengungkapkan ide matematika dalam fenomena dunia nyata melalui gambar atau grafik, tabel, persamaan, ataupun bahasa sehari-hari (Ansari, 2016: 11). Menurut Afgani \& Sutawidjaja (2011: 4.15) komunikasi matematis merupakan suatu kemampuan siswa dalam menulis, membaca, menyimak, menelaah, menginterpretasikan dan mengevaluasi ide, simbol, istilah serta informasi yang berkaitan dengan matematika. Sehingga dapat disimpulkan Kemampuan komunikasi matematis adalah kemampuan siswa dalam menyampaikan ide matematika baik secara lisan maupun tulisan. 
Indikator kemampuan komunikasi matematis terdiri dari (a) mengekspresikan ide-ide matematika melalui lisan, tertulis dan mendemonstrasikan serta menggambarkan secara visual, (b) kemampuan memahami, menginterpretasikan, dan mengevaluasikan ide-ide matematika baik secara lisan maupun dalam bentuk visual lainnya; (c) kemampuan dalam menggunakan istilahistilah, notasi-notasi matematika dan strukturnya untuk menyajikan ide, menggambarkan hubungan dan model situasi (NCTM, 2000: 214). Sedangkan Sumarmo (Afgani \& Sutawidjaja, 2011: 4.16) terdapat juga beberapa indikator yang dapat mengukur kemampuan komunikasi matematis siswa yaitu: (a) menghubungkan benda nyata, gambar dan diagram ke dalam ide matematika, (b) menjelaskan ide, situasi, dan relasi matematika baik secara lisan maupun tulisan dengan benda nyata, gambar, grafik atau bentuk aljabar, (c) Menyatakan peristiwa sehari-hari dalam bahasa atau simbol matematika, (d) Mendengar, mendiskusi dan menulis tentang matematika, (e) Membaca presentasi matematika tertulis dan menyusun pertanyaan yang relevan (f) Membuat konjektur, menyusun argumen, merumuskan definisi, dan generalisasi. Berdasarkan indikator yang dikemukakan oleh beberapa ahli di atas, adapun indikator kemampuan komunikasi dalam penelitian ini adalah menghubungkan benda nyata, gambar ke dalam ide matematika, menjelaskan ide dengan mengkonstruk model konseptual seperti gambar, atau bentuk aljabar, menyatakan peristiwa sehari-hari dalam bahasa atau simbol matematika (membuat model).

Adapun indikator kemampuan komunikasi matematis dalam penelitian ini diambil dari beberapa indakator menurut para ahli yaitu menghubungkan benda nyata, gambar ke dalam ide matematika. menjelaskan ide dengan mengkonstruk model konseptual seperti gambar, atau bentuk aljabar, menyatakan peristiwa sehari-hari dalam bahasa atau simbol matematika (membuat model).

\section{Keterlibatan Siswa}

Menurut Kamus Besar Bahasa Indonesia (KBBI) keterlibatan adalah keadaan terlibatnya seseorang. Menurut Trowler (2010: 3) keterlibatan siswa berkaitan dengan interaksi antara waktu, usaha dan sumber daya relevan lainnya yang ditanamkan oleh siswa untuk mengoptimalkan pengalaman dan meningkatkan hasil belajar. Newman (1992: 12) mendefinisikan keterlibatan sebagai cara yang dilakukan agar siswa terarah menuju kondisi belajar dengan usaha psikologisnya, memahami atau menguasai pengetahuan, keterampilan atau kerajinan tangan karya akademis yang dapat di dipromosikan. Istilah keterlibatan siswa digunakan dalam arti luas yang merujuk pada sikap siswa terhadap sekolah dan partisipasi mereka dalam kegiatan sekolah (Willms, 2003: 8). Jadi, berdasarkan definisi yang dikemukakan di atas dapat disimpulkan bahwa keterlibatan siswa adalah peran aktif siswa untuk memiliki kemauan dalam kegiatan rutin dengan indikator perilaku, emosional dan kognitif selama pembelajaran di sekolah. Peneliti menggunakan dua indikator keterlibatan menurut Watson (2007: 10) yaitu: (a) kelancaran matematis/ mathematical fluency (MF) yang meliputi meniru objek/ menyalin objek, mengikuti prosedur, menemukan jawaban dengan menggunakan prosedur, memberikan jawaban. (b) pembuatan sintesis dan koneksi/synthesis and connection $(M S)$ meliputi diantaranya yaitu klarifikasi, mengasosiasikan gagasan, generalisasi, redescription, meringkas pengembangan gagasan, abstraksi, formalisasi, membuat definisi baru. Alasan peneliti hanya memilih dua indikator menurut Watson karena indikator tersebut memiliki keterkaitan dengan indikator kemampuan komunikasi matematis. Indikator kemampuan komunikasi matematis membuat model matematika berkaitan dengan indikator keterlibatan making synthesis and connection (MS) karena siswa dituntun harus mampu menemukan sebuah model kemudian siswa juga harus mampu mengkomunikasikannya/menjelaskan kepada temantemannya. Sedangkan untuk indikator keterlibatan mathematical fluency (MF) berkaitan dengan semua indikator kemampuan komunikasi matematis, karena siswa harus mampu memahami dan menyelesaikan soal dengan baik menggunakan prosedur yang benar. 


\section{Pendekatan Realistic Mathematics Education (RME)}

RME merupakan suatu pendekatan pembelajaran yang mengkondisikan peserta didik pada masalah kentekstual yang diawal pembelajaran untuk mengarahkan peserta didik dalam memahami suatu konsep matematika (Tarigan, 2006: 3). RME merupakan suatu pendekatan pembelajaran matematika yang lebih menekankan realitas dan lingkungan sebagai titik awal dari pembelajaran (Rahayu, 2010: 15). Siswa juga diajak berpikir cara menyelesaikan masalah yang pernah dialami. Sardiman (2006: 89) juga mengatakan RME adalah pendekatan pembelajaran di bidang matematika yang didasari pada pengalaman-pengalaman siswa dan siswa sendiri yang akan mengaitkan antara pengalaman-pengalaman tersebut dengan konsep-konsep matematika ke dalam pikirannya. Sehingga dapat disimpulkan bahwa RME adalah suatu pendekatan pembelajaran matematika yang dimulai dengan cara mengaitkan materi belajar dengan situasi dunia nyata disekitar siswa. Adapun karakteristik RME dalam penelitian ini diadopsi dari Gravemeijer (1994: 114) yang merumuskan lima karakteristik RME yaitu, (1) Penggunaan konteks adalah permasalahan realistik digunakan sebagai titik awal pembelajaran matematika. (2) Menggunakan berbagai model yang berfungsi sebagai jembatan dari pengetahuan dan matematika merupakan tingkat konkrit menuju pengetahuan matematika tingkat formal, (3) Konstribusi siswa merupakan kebebasan untuk mengembangkan strategi pemecahan masalah sehingga diharapkan akan diperoleh strategi yang bervariasi (4) Interaktif siswa dengan guru, siswa dengan siswa, serta siswa dengan perangkat pembelajaran merupakan hal yang sangat penting dalam pembelajaran matematika realistik. (5) Keterkaitan konsep-konsep dalam matematika tidak bersifat parsial, namun banyak konsep matematika yang memiliki keterkaitan. Melalui keterkaitan ini, pembelajaran matematika diharapkan bisa mengenalkan dan membangun lebih dari satu konsep matematika secara bersamaan.

Adapun indikator RME yang berkaitan dengan keterlibatan siswa yaitu pengunaan konteks dan interaktivitas. Komunikasi/percakapan dan keterlibatan siswa dalam bentuk kontekstual dapat membantu siswa pada saat proses pembelajaran (Johar, Patahuddin dan Widjaja, 2017: 123). Melalui penggunaan konteks diawal pembelajaran juga dapat meningkatkan motivasi serta keterkaitan siswa dalam belajar matematika dan melalui interaktivitas proses belajar seseorang bukan hanya untuk individu saja melainkan juga proses belajar siswa akan menjadi lebih singkat dan bermakna ketika siswa saling mengkomunikasikan hasil kerja dan gagasan mereka. Jika pembelajaran yang diajarkan berkaitan dengan kehidupan nyata maka akan mudah untuk dipahami dan dimengerti oleh siswa. Selain itu karakteristik dan prinsip yang dimiliki RME dapat meningkatkan komunikasi matematis siswa. Siswa belajar dari suatu masalah kontekstual yang berdekatan dengan kehidupan sehari-hari sehingga dapat memunculkan suatu konsep matematika. Masalah kontekstual tersebut, siswa mampu mengembangkan model-model matematika sendiri menuju matematika yang lebih formal. Melalui model matematisasi tersebut menjadi model of untuk membentuk pengetahuan informal dan model for untuk pengetahuan formal. Dalam diskusi kelompok siswa akan memberikan pendapat terhadap model-model yang telah mereka temukan, sehingga terbentuklah suatu interkatifitas diantara mereka. Dengan demikian siswa akan belajar berkomunikasi.

Johar (2016: 122) mengatakan bahwa aspek positif dalam pembelajaran matematika dengan menggunakan realistik yaitu siswa memiliki rasa ingin tahu yang tinggi dalam menyelesaikan masalah matematika karena memiliki kaitan dengan menumbuhkan rasa keingintahuan siswa yang tinggi dalam menyelesaikan masalah matematika terkait dengan kehidupan sehari-hari, menjadikan siswa lebih aktif dan kreatif serta selalu berupaya mencari strategi menyelesaikan suatu masalah dan berani mengungkapkan idea atau pendapat sendiri, dan menumbuhkan rasa senang siswa dalam belajar matematika.

\section{Metode Penelitian}

1. Jenis Penelitian

Penelitian ini merupakan penelitian kualitatif yang bertujuan untuk memperoleh gambaran seutuhnya mengenai kemampuan komunikasi matematis siswa selama pembelejaran 
Lisa Ramadhani, Rahmah Johar, Bansu Irianto Ansari: Kemampuan Komunikasi Matematis ditinjau dari Keterlibatan Siswa melalui Pendekatan Realistic Mathematics Education (RME)

yang ditinjau dari keterlibatan siswa. Penelitian ini berusaha mendeskripsikan kemampuan komunikasi matematis ditinjau dari keterlibatan siswa melalui pendekatan RME pada materi segiempat di kelas VII SMP.

\section{Waktu dan Tempat Penelitian}

Penelitian ini dilaksanakan pada semester genap tahun pelajaran 2018/2019. Tempat pelaksanaan penelitian yaitu SMP IT Al-Azhar Banda Aceh. Penelitian ini berlangsung selama tiga kali pertemuan.

\section{Subjek Penelitian}

Subjek penelitian ini adalah siswa kelas VII-1 SMP IT Al-Azhar Banda Aceh yang berjumlah 24 siswa. Peneliti memilih 6 subjek berdasarkan keterlibatan siswa dalam pembelajaran. Kriteria pemilihan subjek tersebut berdasarkan siswa yang memenuhi semua indikator keterlibatan (tinggi), siswa yang memenuhi beberapa indikator keterlibatan (sedang) dan siswa yang tidak memenuhi indikator keterlibatan (rendah).

\section{Prosedur}

Prosedur penelitian dimulai dengan tahap persiapan yaitu peneliti menyusun instrumen tes kemampuan komunikasi matematis, lembar observasi keterlibatan, melalui pendekatan RME yang kemudian divalidasi oleh validator serta melakukan revisi terhadap instrumen sebelum digunakan dalam penelitian. Tahap selanjutnya melakukan penelitian. Siswa diberikan tes untuk mengetahui kemampuan awal komunikasi matematis. Kemudian dilakukan penilaian terhadap jawaban siswa untuk mengetahui kemampuan komunikasi matematis siswa dalam menyelesaikan permasalahan selama proses pembelajaran melalui pendekatan RME pada materi segiempat. Peneliti mengajar dengan pendekatan RME pada materi segiempat sebanyak tiga kali pertemuan dan melaksanakan pembelajaran sesuai dengan RPP yang telah dirancang. Selama proses penelitian berlangsung peneliti memberikan lembar observasi kepada observer untuk mengamati keterlibatan siswa selama proses pembelajaran. Kemudian pada akhir pembelajaran, siswa diberikan soal tes materi segiempat yang memenuhi indikator kemampuan komunikasi matematis. Tahapan terakhir dalam penelitian ini yaitu analisis data dengan cara mereduksi data, menyajikan data dan menarik kesimpulan.

\section{Data, Instrumen, dan Teknik Pengumpulan Data}

Data yang diperlukan dalam penelitian ini adalah nilai kemampuan komunikasi matematis siswa dan keterlibatan siswa selama pembelajaran berlangsung. Adapun instrumen pengumpulan data yang digunakan yaitu soal kemampuan komunikasi matematis dan lembar observasi keterlibatan siswa selama pembelajaran. Selanjutnya teknik pengumpulan data pada penelitian ini yaitu observasi, tes kemampuan komunikasi matematis. Berikut uraian teknik pengumpulan data dalam penelitian ini :

\section{a. Observasi}

Observasi dilakukan untuk melihat aktivitas yang dilakukan siswa ketika proses pembelajaran berlangsung serta untuk memperoleh data berkenaan dengan keterlibatan siswa yang akan diukur. Instrument yang digunakan pada observasi ini adalah lembar observasi. Lembar observasi keterlibatan siswa diadaptasi dari Watson (2007: 10) yaitu (1) kelancaran matematis/ mathematical fluency (MF), indikatornya yaitu meniru objek/menyalin objek, mengikuti prosedur, menemukan jawaban dengan menggunakan prosedur, memberikan jawaban dan (2) Sintesis dan koneksi/ synthesis and connection (MS), indikatornya yaitu klasifikasi, mengasosiasikan gagasan, generalisasi, redescription, meringkas gagasan, abstraksi, formalisasi, membuat definisi baru. Peneliti akan memberikian centang pada point yang telah dilakukan siswa pada saat pembelajaran berlangsung. 


\section{b. Tes kemampuan Komunikasi Matematis}

Tes ini digunakan untuk memperoleh data kemampuan komunikasi matematis siswa. Tes diberikan pada akhir pertemuan yaitu pada pertemuan ketiga. Soal yang digunakan berupa soalsoal yang berkaitan dengan kemampuan komunikasi matematis pada materi segiempat. Tes yang diberikan terdiri dari tiga soal esai yang memenuhi ketiga indikator kemampuan komunikasi matematis. Soal tes dikembangkan oleh peneliti dan divalidasi oleh dua pakar dan satu guru SMP. Soal tes tersebut dapat dilihat pada Tabel 1.

Tabel 1. Indikator Kemampuan Komunikasi Matematis dan Soal Kemampuan Komunikasi Matematis

Indikator Kemampuan Soal Kemampuan Komunikasi

Komunikasi Matematis

Menghubungkan benda nyata, Toni dan temannya sedang membuat denah rumah. gambar ke dalam ide matematika, Diketahui keliling denah tersebut adalah $26 \mathrm{~cm}$, panjang $4 \mathrm{x}$ dan lebar $x+3$. Bantulah Toni dan temannya untuk:

a. Menurutmu bagaimana sketsa denah rumah tersebut berdasarkan informasi yang diketahui!

b. Hitunglah nilai $x$ ?

c. Berdasarkan nilai $\mathrm{x}$ yang telah diketahui tentukanlah panjang dan lebar denah rumah tersebut!

Menjelaskan ide dengan Sebidang lantai berbentuk persegi panjang berukuran $3 \mathrm{~m} \mathrm{x}$ mengkonstruk model konseptual $4 \mathrm{~m}$ yang akan ditutupi keramik persegi berukuran $50 \mathrm{~cm}$. seperti gambar dan bentuk aljabar Menyatakan peristiwa sehari-hari dalam bahasa atau simbol matematika (membuat model).

Tentukan banyak keramik yang dibutuhkan!

Sebidang tanah berbentuk jajargenjang. Di bagian tengah tanah tersebut akan dibuat taman bunga dengan ukuran panjang $30 \mathrm{~m}$ dan tinggi jajargenjang $12 \mathrm{~m}$. di sekeliling taman bunga akan dibuat jalan, jika lebar jalan 1,5 meter, tentukanlah luas jalan itu?

\section{Teknik Analisis Data}

Teknik analisis data dalam penelitian ini melalui 3 tahapan yaitu reduksi data, penyajian data dan penarikan kesimpulan. Reduksi data berarti merangkum hal-hal pokok yang relevan dengan tujuan penelitian. Kemudian memeriksa hasil jawaban subjek pada saat tes akhir dengan menggunakan rubric penilaian kemampuan komunikasi matematis, peneliti merangkum hasil wawancara dengan subjek secara kualitatif deskriptif dan melihat kembali lembar observasi keterlibatan siswa, kemudian peneliti mendeskripsikan berdasarkan indikator keterlibatan siswa.

Penyajian data dalam penelitian ini yaitu menyajikan data dalam bentuk tabel dan dideskripsikan mengenai hasil tes akhir kemampuan komunikasi matematis berdasarkan rubrik kemampuan komunikasi matematis kemudian . tes yang diberikan pada pertemuan terkahir yaitu 3 soal.

Penarikan kesimpulan dari data yang telah dikumpulkan dan memverifikasi kesimpulan tersebut. Verifikasi dilakukan dengan meninjau ulang catatan lapangan yang telah dibuat. Penarikan kesimpulan dalam penelitian ini bertujuan untuk mendeskripsikan kemampuan komunikasi matematis ditinjau dari keterlibatan siswa melalui pendekatan RME.

\section{Hasil Penelitian dan Pembahasan}

1. Hasil Penelitian

a. Keterlibatan siswa selama pembelajaran melalui pendekatan Realistic Mathematics Education

Keterlibatan siswa melalui pendekatan Realistic Mathematics Education (RME) dilihat dari hasil observasi. Observasi tersebut dilakukan berdasarkan indikator-indikator keterlibatan 
Lisa Ramadhani, Rahmah Johar, Bansu Irianto Ansari: Kemampuan Komunikasi Matematis ditinjau dari Keterlibatan Siswa melalui Pendekatan Realistic Mathematics Education (RME)

siswa yang diadaptasi dari Watson (2007: 10) yaitu: (1) kelancaran matematis/ mathematical fluency (MF) yang meliputi meniru objek/menyalin objek, mengikuti prosedur, menemukan jawaban dengan menggunakan prosedur, memberikan jawaban. (2) pembuatan sintesis dan koneksi/ synthesis and connection (MS) yang meliputi klarifikasi, mengasosiasikan gagasan, generalisasi, redescription, meringkas pengembangan gagasan, abstraksi, formalisasi, membuat definisi baru. Siswa yang di observasi sebanyak enam orang siswa.

Berikut diuraikan hasil observasi keterlibatan siswa ketika proses pembelajaran matematika melalui pendekatan Realistic Mathematics Education pada pertemuan pertama, kedua dan ketiga

Tabel 2. Hasil Observasi Keterlibatan Siswa (Student Engagement) pada Pertemuan Pertama

\begin{tabular}{|c|c|c|c|c|c|c|}
\hline Indikator & MK & WA & MN & MP & NS & ML \\
\hline Meniru objek/menyalin objek & $\sqrt{ }$ & $\sqrt{ }$ & $\sqrt{ }$ & $\sqrt{ }$ & $\sqrt{ }$ & $\sqrt{ }$ \\
\hline Mengikuti prosedur, & $\sqrt{ }$ & $\sqrt{ }$ & $\sqrt{ }$ & $\sqrt{ }$ & $\sqrt{ }$ & $\sqrt{ }$ \\
\hline $\begin{array}{l}\text { Menemukan jawaban dengan menggunakan } \\
\text { prosedur }\end{array}$ & $\sqrt{ }$ & $\sqrt{ }$ & $\sqrt{ }$ & $\sqrt{ }$ & $\sqrt{ }$ & $\sqrt{ }$ \\
\hline Memberikan jawaban & $\sqrt{ }$ & $\sqrt{ }$ & $\sqrt{ }$ & $\sqrt{ }$ & $\sqrt{ }$ & $\sqrt{ }$ \\
\hline Klarifikasi (mengecek kebenaran) & $\sqrt{ }$ & $\sqrt{ }$ & $\sqrt{ }$ & $\sqrt{ }$ & - & - \\
\hline $\begin{array}{l}\text { Mengasosiasikan gagasan (mengolah } \\
\text { informasi) }\end{array}$ & $\sqrt{ }$ & $\sqrt{ }$ & $\sqrt{ }$ & $\sqrt{ }$ & $\sqrt{ }$ & $\sqrt{ }$ \\
\hline Generalisasi, (membentuk simpulan umum) & $\sqrt{ }$ & $\sqrt{ }$ & $\sqrt{ }$ & $\sqrt{ }$ & - & - \\
\hline $\begin{array}{l}\text { Redescription (mendeskripsikan jawabannya } \\
\text { sendiri) }\end{array}$ & $\sqrt{ }$ & $\sqrt{ }$ & $\sqrt{ }$ & $\sqrt{ }$ & - & - \\
\hline $\begin{array}{l}\text { Meringkas pengembangan ide } \\
\text { Abstraksi }\end{array}$ & $\sqrt{ }$ & $\sqrt{ }$ & $\sqrt{ }$ & $\sqrt{ }$ & $\sqrt{ }$ & - \\
\hline $\begin{array}{l}\text { Formalisasi } \\
\text { Membuat definisi baru }\end{array}$ & $\sqrt{ }$ & $\sqrt{ }$ & $\sqrt{ }$ & $\sqrt{ }$ & $\sqrt{ }$ & $\sqrt{ }$ \\
\hline
\end{tabular}

Berdasarkan proses pembelajaran di hari pertama, terlihat pada Tabel 2 bahwa subjek MK, WA, MN, MP mampu menunjukkan keterlibatan yang sama selama pembelajaran berlangsung. Namun NS tidak terlibat dalam hal memberikan klarifikasi, mengasosiasikan gagasan, generalisasi, redescription. Sedangkan ML juga tidak terlibat dalam hal klarifikasi, generalisasi, redescription, dan meringkas pengembangan ide.

Tabel 3. Hasil Observasi Keterlibatan Siswa (Student Engagement) pada Pertemuan Kedua

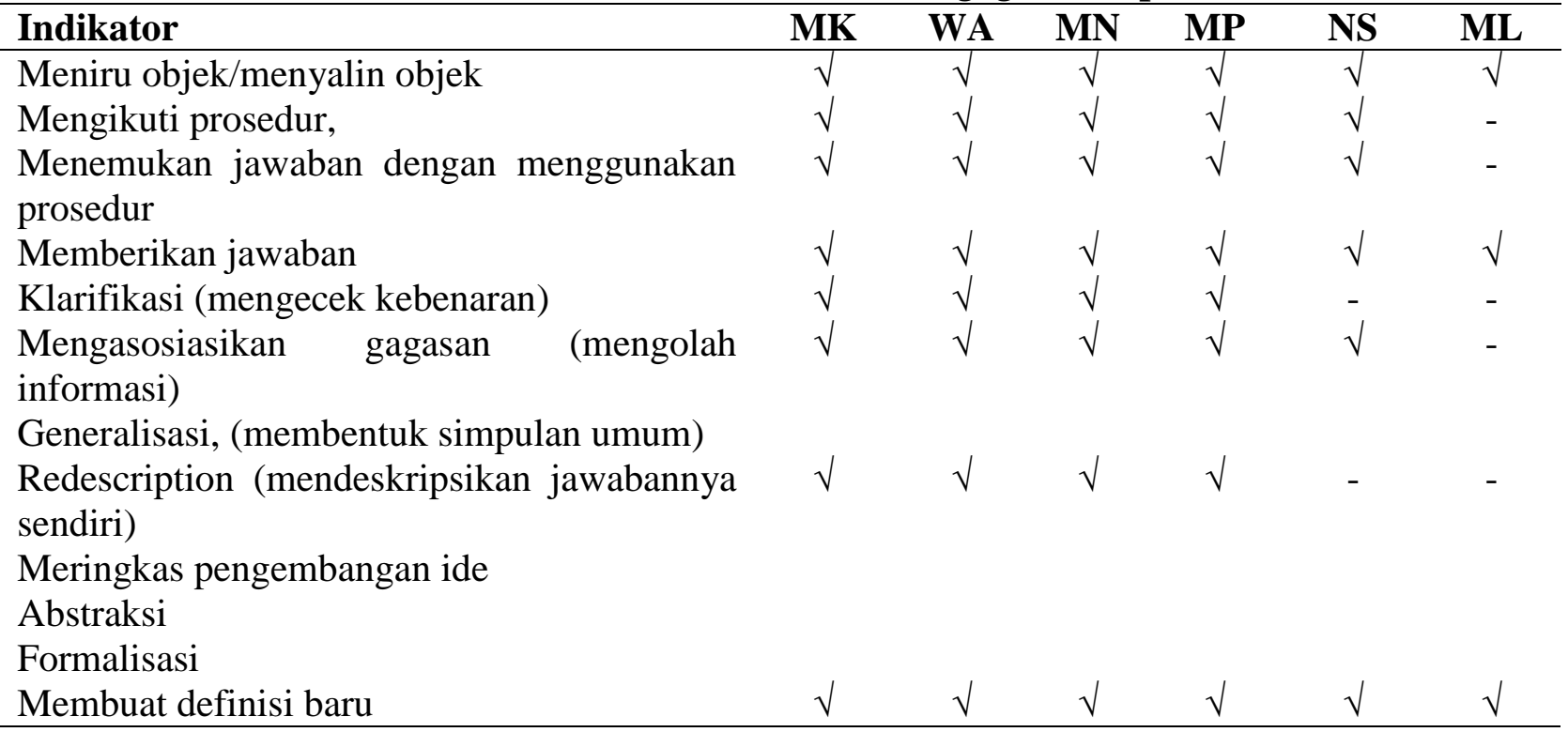


Dari Tabel 3 dapat dilihat bahwa subjek MN, WA, MN, dan MP mampu memenuhi semua indikator keterlibatan. Akan tetapi terdapat dua subjek yang tidak memenuhi beberapa indikator keterlibatan yaitu subjek NS dan ML. Subjek NS hanya terlibat dalam hal meniru atau menyalin objek, mengikuti prosedur, menemukan jawaban dengan menggunakan prosedur, dan memberikan jawaban. Sedangkan subjek ML hanya terlibat dalam hal meniru /menyalin objek dan mampu memberikan jawaban.

Tabel 4. Hasil Observasi Keterlibatan Siswa (Student Engagement) pada Pertemuan Ketiga

\begin{tabular}{lcccccc}
\hline Indikator & MK & WA & MN & MP & NS & ML \\
\hline Meniru objek/menyalin objek & $\sqrt{ }$ & $\sqrt{ }$ & $\sqrt{ }$ & $\sqrt{ }$ & $\sqrt{ }$ & $\sqrt{ }$ \\
Mengikuti prosedur, & $\sqrt{ }$ & $\sqrt{ }$ & $\sqrt{ }$ & $\sqrt{ }$ & $\sqrt{ }$ & - \\
Menemukan jawaban dengan menggunakan & $\sqrt{ }$ & $\sqrt{ }$ & $\sqrt{ }$ & $\sqrt{ }$ & $\sqrt{ }$ & - \\
prosedur & & & & & & \\
Memberikan jawaban & $\sqrt{ }$ & $\sqrt{ }$ & $\sqrt{ }$ & $\sqrt{ }$ & $\sqrt{ }$ & $\sqrt{ }$ \\
Klarifikasi (mengecek kebenaran) & $\sqrt{ }$ & $\sqrt{ }$ & $\sqrt{ }$ & $\sqrt{ }$ & $\sqrt{ }$ & - \\
$\begin{array}{l}\text { Mengasosiasikan gagasan (mengolah } \\
\text { informasi) }\end{array}$ & $\sqrt{ }$ & $\sqrt{ }$ & $\sqrt{ }$ & $\sqrt{ }$ & $\sqrt{ }$ & - \\
Generalisasi, (membentuk simpulan umum) & $\sqrt{ }$ & $\sqrt{ }$ & $\sqrt{ }$ & $\sqrt{ }$ & - & - \\
Redescription (mendeskripsikan jawabannya & $\sqrt{ }$ & $\sqrt{ }$ & $\sqrt{ }$ & $\sqrt{ }$ & - & - \\
sendiri) & & & & & & \\
Meringkas pengembangan ide & & & & & & - \\
Abstraksi & $\sqrt{ }$ & $\sqrt{ }$ & $\sqrt{ }$ & $\sqrt{ }$ & - & - \\
Formalisasi & $\sqrt{ }$ & $\sqrt{ }$ & $\sqrt{ }$ & $\sqrt{ }$ & - & - \\
Membuat definisi baru & & & & & \\
\hline
\end{tabular}

Dari Tabel 4 dapat dilihat bahwa terdapat lima subjek yang memenuhi semua indikator keterlibatan, sedangkan hanya satu orang saja yang belum memenuhi keseluruhan dari indikator keterlibatan. Subjek yang memenuhi semua indikator keterlibatan yaitu MK, WA, MN, MP sedangkan subjek NS tidak terlibat pada indikator generalisasi, redescription, abstraksi dan formalisasi, apalagi subjek ML hanya terlibat pada meniru objek/menyalin objek, mengikuti prosedur dan memberikan jawaban.

Tabel 5. Keterlibatan Siswa (Student Engagement) Selama Tiga Pertemuan

\begin{tabular}{cccc}
\hline & \multicolumn{2}{c}{ Jumlah Indikator Keterlibatan yang dipenuhi } \\
\cline { 2 - 4 } Subjek & Pertemuan 1 & Pertemuan 2 & Pertemuan \\
& & & $\mathbf{3}$ \\
MK (tinggi) & 10 & 7 & 10 \\
WA (tinggi) & 10 & 7 & 10 \\
MN (sedang) & 10 & 7 & 10 \\
MP (sedang) & 10 & 5 & 10 \\
NS (rendah) & 7 & 2 & 6 \\
ML (rendah) & 6 & $83,3 \%$ & 2 \\
\hline Persentase & $88,3 \%$ & & $78,3 \%$ \\
\hline
\end{tabular}

Subjek yang mampu memenuhi semua indikator keterlibatan yaitu MK, WA, MN dan MP. Sedangkan subjek yang hanya memenuhi beberapa indikator keterlibatan yaitu NS dan ML. Adapun indikator keterlibatan yang dimaksud adalah meniru objek/menyalin objek, mengikuti prosedur, menemukan jawaban dengan menggunakan prosedur, memberikan jawaban, klarifikasi, mengasosiasikan gagasan, generalisasi, redescription, meringkas pengembangan gagasan, abstraksi, formalisasi, membuat definisi baru. Pada pertemuan pertama, subjek NS tidak memenuhi indikator klarifikasi dikarenakan pada saat kerja kelompok subjek hanya 
memberikan jawabannya saja, subjek juga tidak memberikan kesimpulan umum mengenai pengertian bentuk-bentuk bangun datar segiempat. Subjek NS hanya dapat menentukan sifatsifat bangun datar segiempat saja. Ketika membuat kesimpulan secara umum mengenai bangun datar segiempat NS terlihat hanya diam saja dalam kelompoknya dan mendengarkan apa yang di ucapkan oleh temannya. Subjek NS juga tidak mampu untuk mendeskripsikan jawabannya sendiri secara lisan, akan tetapi subjek mampu memberikan jawaban mengenai sifat-sifat bangun datar segiempat dan subjek ikut membuat sebuah definisi mengenai bentuk-bentuk bangun datar segiempat pada saat kerja kelompok. Dari tabel 5 terlihat bahwa subjek dengan kemampuan komunikasi matematis tinggi dan sedang memiliki keterlibatan yang baik saat pembelajaran. Mereka saling berdiskusi dalam kelompok untuk meyelesaikan suatu masalah yang diberikan. Sedangkan subjek dengan kemampuan komunikasi matematis rendah kurang terlibat ketika pembelajaran berlangsung hal ini terlihat ketika pembelajaran sedang berlangsung mereka sibuk dengan kegiatannya sendiri.

Pada pertemuan pertama subjek ML tidak memberikan klarifikasi terhadap jawaban mengenai sifat-sifat yang terdapat pada bangun datar segiempat yang diberikan, karena menurut subjek jawaban yang diberikan sudah benar sehingga tidak perlu diklarifikasi lagi. Sedangkan dari jawaban yang diperolehnya, subjek tidak mampu untuk mendeskripsikan jawaban karena ketika dalam kelompoknya subjek hanya menceklist sifat-sifat yang ada pada bangun datar. Sehingga subjek ML tidak mampu meringkas pengembangan idenya untuk membuat sebuah definisi baru mengenai bentuk-brntuk bangun datar segiempat.

Keterlibatan subjek NS dan ML dipertemuan kedua juga masih memenuhi beberapa dari indikator keterlibatan. Subjek NS tidak mengklarifikasikan jawaban yang diberikan, karena permasalahan yang diberikan diselesaikan secara bersamaan dengan teman kelompoknya sehingga sudah ada diskusi pada saat menjawab permasalahan tersebut. Ketika memberikan jawaban, subjek tidak mendeskripsikan jawaban yang diberikan kepada anggota kelompoknya. Subjek sulit untuk menjelaskan alasan memperoleh jawaban, sehingga subjek hanya memberikan jawabannya saja. Subjek ML tidak mampu mengikuti prosedur serta tidak mampu menemukan jawaban dengan menggunakan prosedur ketika bekerja dalam kelompoknya, hal ini dikerenakan subjek belum paham maksud dari permasalahan yang diberikan, sehingga subjek sulit untuk mengolah informasi dan mendeskripsikan jawabannya.

Permasalahan yang diberikan pada LKPD pada pertemuan ketiga yaitu bagaimana cara menemukan rumus luas jajargenjang. Subjek MK, WA, MN dan MP memenuhi semua indikator keterlibatan. Sedangkan subjek NS dan ML hanya memenuhi beberapa indikator keterlibatan. Subjek NS hanya mampu mendeskripsikan hubungan antara tinggi jajargenjang dengan lebar pada persegi panjang serta hubungan antara alas jajargenjang dengan panjang pada persegi panjang. Akan tetapi subjek NS tidak mampu untuk membentuk sebuah kesimpulan mengenai rumus jajargenjang. Subjek tidak bisa membuat sebuah intisari dari konsep persegi panjang dan jajargenjang, sehingga subjek tidak mampu menemukan rumus luas jajargenjang.

Subjek ML ikut memberikan jawaban ketika belajar kelompok akan tetapi jawaban yang diberikan tidak sesuai dengan prosedur. Subjek hanya memberikan jawaban saja tanpa mengetahui cara penyelesaian. Hal ini disebabkan karena subjek belum memahami permasalahan yang diberikan. Sehingga subjek tidak mampu untuk menemukan rumus luas jajargenjang.

\section{b. Kemampuan komunikasi matematis siswa}

Data kemampuan komunikasi matematis siswa dapat dilihat pada Tabel 6. Berdasarkan Tabel 6 dapat disimpulkan 5 dari 6 subjek telah mencapai ketiga indikator kemampuan komunikasi matematis. Subjek MK memenuhi ketiga indikator kemampuan komunikasi matematis. Pada indikator menghubungkan benda nyata, gambar dan diagram ke dalam ide matematika, subjek sudah mampu menyelesaikan permasalahan yang diberikan, akan tetapi subjek masih terdapat kekeliruan dalam proses penyelesaian masalah. Sedangkan untuk indikator menjelaskan ide dengan mengkonstruk model konseptual seperti gambar, grafik, tabel, diagram atau bentuk aljabar dan indikator menyatakan peristiwa sehari-hari dalam bahasa atau simbol matematika 
subjek MK juga sudah memenuhi indikator tersebut. Subjek WA memenuhi tiga indikator kemampuan komunikasi matematis. Subjek mampu menyelesaikan permasalahan yang diberikan dengan baik. Subjek MN juga memenuhi ketiga indikator kemampuan komunikasi matematis. Akan tetapi subjek MN masih banyak keliru dalam proses perhitungan. Sedangkan subjek MP mampu memenuhi indikator kemampuan komunikasi matematis, walaupun subjek masih susah dalam memahami bentuk soal yang diberikan. Subjek NS memenuhi dua dari tiga indikator kemampuan komunikasi matematis yaitu indikator menjelaskan ide dengan mengkonstruk model konseptual seperti gambar, grafik, tabel, diagram atau bentuk aljabar dan indikator menyatakan peristiwa sehari-hari dalam bahasa atau simbol matematika. Subjek NS masih kurang dalam memahami soal sehingga terdapat beberapa kesalahan yang dilakukan pada saat menyelesaikan permasalahan yang diberikan. Secara umum subjek masih kurang memahami soal. Subjek ML tidak memenuhi ketiga indikator keterlibatan, dan subjek juga tidak memahami permasalahan yang diberikan. Berdasarkan wawancara diketahui bahwa subjek ML belum memahami soal dengan baik karena subjek ML mendapatkan jawaban dari kawannya.

Tabel 6. Data Hasil Penilaian Tes Kemampuan Komunikasi Matematis Siswa

\begin{tabular}{|c|c|c|c|c|c|c|c|}
\hline \multirow[t]{2}{*}{ Subjek } & \multicolumn{4}{|c|}{ Nomor Soal } & \multirow{2}{*}{$\begin{array}{l}\text { Jumlah } \\
\text { Nilai }\end{array}$} & \multirow{2}{*}{$\begin{array}{c}\text { Rata-rata skor } \\
\text { kemampuan } \\
\text { komunikasi }\end{array}$} & \multirow[t]{2}{*}{ Kriteria } \\
\hline & 1 & $2 a$ & $2 b$ dan $2 c$ & 3 & & & \\
\hline MK & 4 & 4 & 4 & 4 & 16 & 4 & Sangat Baik \\
\hline WA & 4 & 4 & 4 & 4 & 16 & 4 & Sangat Baik \\
\hline $\mathrm{MN}$ & 4 & 4 & 3 & 4 & 15 & 3,75 & Sangat Baik \\
\hline MP & 4 & 4 & 4 & 4 & 16 & 4 & Sangat Baik \\
\hline NS & 4 & 2 & 4 & 3 & 14 & 3,25 & Baik \\
\hline ML & 1 & 1 & 1 & 1 & 4 & 1 & Kurang \\
\hline
\end{tabular}

Pencapaian kemampuan komunikasi matematis oleh subjek MK, WA, MN, MP, NS sudah memperoleh pembelajaran dengan baik melalui pendekatan pembelajaran RME. Sedangkan untuk subjek ML belum berdampak dalam pembelajaran sehingga subjek masih banyak memerlukan bantuan guru dan teman sejawat dalam proses pembelajaran.

\section{c. Kemampuan komunikasi matematis siswa ditinjau dari keterlibatan siswa}

Hasil observasi keterlibatan siswa dan kemampuan komunikasi matematis selama pembelajaran terhadap enam subjek dapat dilihat pada Tabel 7.

Tabel 7. Keterlibatan Siswa (Student Engagement) dan Kemampuan Komunikasi Matematis Selama Tiga Pertemuan

\begin{tabular}{ccccc}
\hline \multirow{2}{*}{ Subjek } & \multicolumn{3}{c}{$\begin{array}{c}\text { Jumlah Indikator Keterlibatan yang } \\
\text { Dipenuhi }\end{array}$} & $\begin{array}{c}\text { Kriteria Kemampuan } \\
\text { Komunikasi Matematis }\end{array}$ \\
\cline { 2 - 5 } & Pertemuan 1 & pertemuan 2 & pertemuan 3 & \\
\hline MK (tinggi) & 10 & 7 & 10 & Memenuhi 3 indikator \\
WA (tinggi) & 10 & 7 & 10 & Memenuhi 3 indikator \\
MN (sedang) & 10 & 7 & 10 & Memenuhi 3 indikator \\
MP (sedang) & 10 & 7 & 10 & Memenuhi 3 indikator \\
NS (rendah) & 7 & 5 & 6 & Memenuhi 2 indikator \\
ML & 6 & 2 & 2 & Tidak memenuhi indikator \\
(rendah) & & $83,3 \%$ & $78,3 \%$ & \\
\hline Persentase & $88,3 \%$ & &
\end{tabular}

Berdasarkan hasil paparan data yang telah dilakukan, subjek MK dan WA memiliki keterlibatan yang baik selama pembelajaran, sedangkan kemampuan komunikasi matematis subjek tersebut hanya memenuhi 3 indikator. Tes kemampuan komunikasi matematis subjek MN 
Lisa Ramadhani, Rahmah Johar, Bansu Irianto Ansari: Kemampuan Komunikasi Matematis ditinjau dari Keterlibatan Siswa melalui Pendekatan Realistic Mathematics Education (RME)

memenuhi 3 indikator. Sedangkan keterlibatan subjek NS selama pembelajaran melalui pendekatan RME berdampak terlibat dalam kelompoknya. Kemampuan komunikasi matematis Subjek NS memenuhi dua indikator. Selama pembelajaran melalui RME subjek terlihat ikut terlibat pada pertemuan pertama dan terus berkurang keterlibatannya sampai pertemuan ketiga. Sedangkan untuk kemampuan komunikasi matematis selama pembelajaran subjek ML tidak memenuhi ketiga indikator kemampuan komunikasi matematis.

\section{Pembahasan}

Keterlibatan siswa dalam pembelajaran pada pertemuan pertama hingga pertemuan ketiga terdapat empat subjek yang mampu memenuhi semua indikator keterlibatan dan dua subjek hanya memenuhi beberapa indikator keterlibatan. Subjek yang mampu memenuhi indikator keterlibatan yaitu MK, WA, MN dan MP. Sedangkan subjek yang hanya memenuhi beberapa indikator keterlibatan yaitu NS dan ML.

Pertemuan pertama subjek NS tidak memenuhi indikator klarifikasi dikarenakan pada saat kerja kelompok subjek hanya memberikan jawabannya saja, subjek juga tidak memberikan kesimpulan umum mengenai pengertian bentuk-bentuk bangun datar segiempat. Subjek hanya dapat menentukan sifat-sifat bangun datar segiempat saja. Ketika membuat sebuah kesimpulan secara umum mengenai bangun datar segiempat NS terlihat hanya diam saja dalam kelompoknya dan mendengarkan apa yang di ucapkan oleh temannya. Subjek NS juga tidak mampu untuk mendeskripsikan jawabannya sendiri secara lisan, akan tetapi subjek mampu memberikan jawaban mengenai sifat-sifat bangun datar segiempat dan subjek ikut membuat sebuah definisi mengenai bentuk-bentuk bangun datar segiempat pada saat kerja kelompok.

Subjek ML tidak memberikan klarifikasi terhadap jawaban mengenai sifat-sifat yang terdapat pada bangun datar segiempat yang diberikan, karena menurut subjek jawaban yang diberikan sudah benar sehingga tidak perlu diklarifikasi lagi. Sedangkan dari jawaban yang diperolehnya, subjek tidak mampu untuk mendeskripsikan jawaban karena ketika dalam kelompoknya subjek hanya menceklist sifat-sifat yang ada pada bangun datar. Sehingga subjek ML tidak mampu meringkas pengembangan idenya untuk membuat sebuah definisi baru mengenai bentuk-brntuk bangun datar segiempat.

Keterlibatan subjek NS dan ML dipertemuan kedua juga masih memenuhi beberapa dari indikator keterlibatan. Subjek NS tidak mengklarifikasikan jawaban yang diberikan, karena permasalahan yang diberikan diselesaikan secara bersamaan dengan teman kelompoknya sehingga sudah ada diskusi pada saat menjawab permasalahan tersebut. Ketika memberikan jawaban, subjek tidak mendeskripsikan jawaban yang diberikan kepada anggota kelompoknya. Subjek sulit untuk menjelaskan alasan memperoleh jawaban, sehingga subjek hanya memberikan jawabannya saja. Sedangkan subjek ML tidak mampu mengikuti prosedur serta tidak mampu menemukan jawaban dengan menggunakan prosedur ketika bekerja dalam kelompoknya, hal ini dikerenakan subjek belum paham maksud dari permasalahan yang diberikan, sehingga subjek sulit untuk mengolah informasi dan mendeskripsikan jawabannya.

Permasalahan yang diberikan pada LKPD saat pertemuan ketiga yaitu bagaimana cara menemukan rumus luas jajargenjang. Subjek MK, WA, MN dan MP memenuhi semua indikator keterlibatan. Sedangkan subjek NS dan ML hanya memenuhi beberapa indikator keterlibatan. Subjek NS hanya mampu mendeskripsikan hubungan antara tinggi jajargenjang dengan lebar pada persegi panjang serta hubungan antara alas jajargenjang dengan panjang pada persegi panjang. Akan tetapi subjek NS tidak mampu untuk membentuk sebuah kesimpulan mengenai rumus jajargenjang. Subjek tidak bisa membuat sebuah intisari dari konsep persegi panjang dan jajargenjang, sehingga subjek tidak mampu menemukan rumus luas jajargenjang. Subjek ML ikut memberikan jawaban ketika belajar kelompok. Akan tetapi jawaban yang diberikan tidak sesuai dengan prosedur. Subjek hanya memberikan jawaban saja tanpa mengetahui maksud dari jawaban yang diberikannya dan subjek tidak mengklarifikasi jawabannya. Hal ini disebabkan karena subjek belum memahami permasalahan yang diberikan. Sehingga subjek tidak mampu untuk menemukan rumus luas jajargenjang. 
Data kemampuan komunikasi matematis siswa diperoleh melalui tes kemampuan komunikasi matematis. Tes kemampuan komunikasi matematis siswa diberikan setelah siswa mengikuti pelajaran matematika melalui pendekatan RME pada pertemuan terakhir. Soal tes tersebut disusun berdasarkan indikator komunikasi matematis diantaranya yaitu: (1) menghubungkan benda nyata, gambar dan diagram ke dalam ide matematika, (2) menjelaskan ide dengan mengkonstruk model konseptual seperti gambar, grafik, tabel, diagram atuu bentuk aljabar, (3) menyatakan peristiwa sehari-hari dalam bahasa atau simbol matematika (membuat model)

Berdasarkan hasil analisis data dari setiap nilai siswa terhadap kemampuan komunikasi matematis siswa pada materi segiempat dapat disimpulkan telah mencapai kategori baik. Hal ini terlihat bahwa lima dari enam subjek mampu memenuhi indikator yaitu MK, WA, MN, MP, NS. Sedangkan hanya subjek ML yang tidak memenuhi ketiga dari indikator kemampuan komunikasi matematis.

Subjek MK sudah memenuhi ketiga indikator kemampuan komunikasi matematis. Pada indikator menghubungkan benda nyata, gambar dan diagram ke dalam ide matematika, subjek sudah mampu menyelesaikan permasalahan yang diberikan, akan tetapi subjek masih terdapat kekeliruan dalam proses penyelesaian masalah. Sedangkan untuk indikator menjelaskan ide dengan mengkonstruk model konseptual seperti gambar, grafik, tabel, diagram atau bentuk aljabar dan indikator menyatakan peristiwa sehari-hari dalam bahasa atau simbol matematika subjek MK juga sudah memenuhi indikator tersebut. Subjek WA memenuhi tiga indikator kemampuan komunikasi matematis. Subjek mampu menyelesaikan permasalahan yang diberikan dengan baik.

Subjek MN juga sudah memenuhi ketiga indikator kemampuan komunikasi matematis. Akan tetapi subjek MN masih banyak keliru dalam proses perhitungan. Sedangkan subjek MP mampu memenuhi indikator kemampuan komunikasi matematis, walaupun subjek masih susah dalam memahami bentuk soal yang diberikan. Subjek NS memenuhi dua dari tiga indikator kemampuan komunikasi matematis yaitu indikator menjelaskan ide dengan mengkonstruk model konseptual seperti gambar, grafik, tabel, diagram atau bentuk aljabar dan indikator menyatakan peristiwa sehari-hari dalam bahasa atau simbol matematika. Subjek NS masih kurang dalam memahami soal sehingga terdapat beberapa kesalahan yang dilakukan pada saat menyelesaikan permasalahan yang diberikan. Subjek ML tidak memenuhi ketiga indikator keterlibatan, subjek juga tidak memahami permasalahan yang diberikan serta subjek kurang terlibat dalam proses pembelajaran.

Berdasarkan hasil paparan analisis data yang dilakukan peneliti terhadap keterlibatan siswa dan kemampuan komunikasi matematis bahwa subjek MK (keterlibatan tinggi) memenuhi semua dari indikator keterlibatan yaitu subjek mampu meniru objek/menyalin objek, mengikuti prosedur, menemukan jawaban dengan menggunakan prosedur, memberikan jawaban, klarifikasi, mengolah informasi, generalisasi, redescription, meringkas pengembangan ide, abstraksi, formalisasi dan membuat definisi baru. Keterlibatan subjek WA (keterlibatan tinggi) memenuhi semua indikator keterlibatan dan rata-rata untuk kemampuan komuniaksi yaitu 4 dengan kriteria baik. Subjek MN (keterlibatan sedang) juga memenuhi semua indikator keterlibatan selama pembelajaran pertemuan pertama hingga pertemuan ketiga nilai rata-rata untuk kemampuan komunikasi yaitu 3,75 dengan kriteria sangat baik. Subjek MP (keterlibatan sedang) memenuhi semua indikator keterlibatan selama tiga kali pertemuan pembelajaran. Skor rata-rata yang didapat untuk kemampuan komunikasi matematis yaitu 4 dengan kriteria sangat baik. Keterlibatan Subjek NS (keterlibatan rendah) pada pertemuan pertama indikator yang dipenuhi yaitu meniru objek/menyalin objek, mengikuti prosedur, menemukan jawaban dengan menggunakan prosedur, memberikan jawaban, mengolah informasi, meringkas pengembangan ide, dan membuat definisi baru. Adapun indikator keterlibatan yang tidak terpenuhi pada pertemuan pertama yaitu klarifikasi, generalisasi dan redescription sedangkan pada pertemuan kedua indikator keterlibatan yang tidak tercapai yaitu klarifikasi dan redescription dan pada 
pertemuan ketiga yaitu generalisasi, redescription, abstraksi, dan formalisasi. Sedangkan ratarata yang diperoleh untuk kemampuan komunikasi matematis yaitu 3,25 dengan kriteria baik.

Subjek ML (keterlibatan rendah) indikator keterlibatan yang dipenuhi pada pertemuan pertama yaitu meniru/menyalin objek, mengikuti prosedur, menemukan jawaban dengan menggunakan prosedur, memberikan jawaban, mengasosiasikan gagasan dan membuat definisi. Adapun pada pertemuan kedua indikator yang tidak terpenuhi yaitu mengikuti prosedur, menemukan jawaban dengan menggunakan prosedur, klarifikasi, dan redescription. Pertemuan ketiga subjek juga tidak memenuhi beberapa indikator keterlibatan diantaranya mengikuti prosedur, menemukan jawaban dengan menggunakan cara, klarifikasi, mengasosiasikan gagasan, generalisasi, redescription, abstraksi, formalisasi sedangkan rata-rata nilai kemampuan komunikasi yang didapat yaitu 1 dengan kriteria kurang.

Pencapaian kemampuan komunikasi matematis oleh subjek MK, WA, MN, MP, NS sudah berada pada katagori baik, artinya subjek tersebut sudah terlibat secara aktif selama pembelajaran melalui pendekatan pembelajaran RME. Sedangkan untuk subjek ML hanya mendapat sedikit keuntungan dalam pembelajarannya sehingga subjek masih banyak memerlukan bantuan guru dan teman sejawat dalam proses pembelajaran.

Dengan demikian, pendekatan RME dapat menuntut siswa untuk lebih aktif dan harus memiliki keterlibatan dalam membangun serta mengkonstruksi sendiri konsep yang akan diperolehnya, melalui pendekatan ini siswa diajak untuk mempelajari persoalan matematika yang berkaitan dengan kehidupan sehari-hari. Pendekatan RME dapat menuntun siswa untuk lebih terlibat dalam membangun serta mengkonstruksi sendiri konsep yang dipelajari. Melalui pendekatan ini siswa diajak untuk mempelajari persoalan matematika yang berkaitan dengan kehidupan sehari-hari dan mampu melibatkan siswa dalam pembelajaran. Hal ini didukung oleh hasil penelitian yang dilakukan Veralita, Rohaeti dan Purwasih (2018: 122) yang menyatakan bahwa kemampuan komunikasi matematika siswa SMP yang menggunakan pendekatan RME lebih baik daripada yang menggunakan pembelajaran biasa. Melalui RME siswa juga dapat terlibat dalam pembelajaran. Keterlibatan dan diskusi antara siswa memberikan wawasan berharga serta menjadi sebuah inisiatif keterlibatan siswa pada setiap pembelajaran (Drey, 2018). Wawasan siswa terhadap penyelesaian suatu masalah juga akan berdampak pada hasil yang didapatkannya nanti. Selama proses pembelajaran guru memberikan lembar kerja kepada siswa dan dinilai pada saat itu juga, sehingga nilai yang diberikan kepada siswa juga merupakan salah satu faktor penting yang membantu siswa untuk memiliki rasa ingin tahu terhadap penyelesaian suatu permasalahan yang memungkinkan siswa untuk memiliki keterlibatan selama di kelas (Gunuc, 2014: 208). Pembelajaran yang dimulai dengan sesuatu yang rill dapat membuat siswa terlibat langsung dalam proses pembelajaran sehingga membuat membuat pembelajaran lebih bermakna (Wijaya, 2012: 21). Hasil penelitian ini juga didukung oleh pendapat Latioyono (2016: 96) yaitu pembelajaran dengan pendekatan PMRI dapat melatih kemampuan komunikasi matematis siswa.

\section{E. Simpulan}

Berdasarkan hasil penelitian dan pembahasan maka dapat disimpulkan bahwa kemampuan komunikasi matematis ditinjau dari ketelibatan siswa melalui pendekatan RME sudah baik. Hal ini terlihat dari hasil pencapaian kemampuan komunikasi matematis yang ditinjau dari keterlibatan siswa pada subjek MK, WA, MN, MP, NS sudah berada pada katagori baik, artinya subjek telah memperoleh pembelajaran dengan baik karena pada saat pembelajaran subjek yang terlibat aktif juga memiliki kemampuan komunikasi matematis yang baik. Serta penggunaan pendekatan RME juga membangkitkan semangat siswa agar terlibat dalam pembelajaran agar memperoleh kemampuan komunikasi matematis yang baik. Berdasarkan keterlibatan siswa dan kemampuan komunikasi matematis selama pembelajaran dengan menggunakan pendekatan RME dapat dikatakan bahwa siswa yang memiliki keterlibatan aktif selama pembelajaran juga memiliki kemampuan komunikasi matematis yang baik. Namun, dari dua subjek yang keterlibatan rendah hanya memenuhi indikator menyalin gambar dan 
memberikan jawaban dengan menggunakan prosedur tetapi tidak mampu menjelaskan jawabannya.

\section{DAFTAR PUSTAKA}

Ansari, B.I. (2016). Komunikasi matematika, strategi berfikir dan manajemen belajar (konsep dan aplikasi). Banda Aceh: Pena.

Ansari, B. I., \& Sulastri, R. (2018). Improving mathematical representation ability in solving word problems through the use of cognitive strategies: Orientation, organization, and elaboration. Journal of Physics: Conference Series, 1028(1), 1-8.

Susanto, Ahmad. (2013). Teori belajar dan pembelajaran di sekolah dasar. Jakarta: Kharisma Putra Utama.

Baroody. A.J. (1993). Problem solving, reasoning, and communicating. New York: Macmillan Publishing.

Bodovski K, \& Farkas G. (2007). The roles of beginning knowledge, student engagement, and instruction. Mathematics Growth In Early Elementary School. Elem Sch J, 108(2), 115130.

Gunuc, S. (2014). The relationships between student engagement and their academic achievement. International Journal on New Trends in Education and Their Implications, 5(4), 216-231.

Gravemeijer. K. P. E. (1994). Developing realistic mathematics education. Utrecht: Freudenthal Institute.

Johar, R., Patahuddin, S. M., \& Widjaja, W. (2017). Linking pre-service teachers' questioning and students' strategies in solving contextual problems: a case study in indonesia and the netherlands. The Mathematics Enthusiast, 14(1), 101-128.

National Council of Teacher of Mathematics. (2000). Principles and standards for school mathematics. Reston: NCTM.

Ozkaya, A., \& Karaca, S. Y. (2017). The effects of realistic mathematics education on students'achievements and attitudes in fifth grades mathematics courses. International Online Journal Of Education And Teaching, 4(2), 185-197.

Patahuddin, S. M., Puteri, I., Lowrie, T., Logan, T., \& Rika, B. (2018). Capturing student mathematical engagement through differently enacted classroom practices: Applying a modification of watson's analytical tool. International Journal of Mathematical Education in Science and Technology, 49(3), 384-400.

Purniati, T. (2003). Matematik pembelajaran geometri berdasarkan tahap-tahap awal van hiele dalam upaya meningkatkan kemampuan komunikasi siswa SLTP. Tesis, Tidak Dipublikasikan. Universitas Pendidikan Indonesia.

Rahayu, Tika. (2010). Pendekatan RME terhadap peningkatan prestai belajar matematika siswa kelas 2 sd n penaruban I Purbalingga. Yogyakarta: UNY.

Veralita, L., Rohaeti, E.E., \& Purwasih, R. (2018). Meningkatkan kemampuan komunikasi matematik dan kemandirian belajar siswa smp melalui pendekatan realistic mathematics education. AKSIOMA: Jurnal Matematika dan Pendidikan Matematika, 9(1), 113-123.

Salim, N.R., \& Ayub, A.F.M. (2017). Relationship between mathematics statistics engagement and attitudes towards statistics among undergraduate students in malaysia. In AIP Conference Proceedings, 179(1). AIP Publishing.

Soedjadi, R. (2010). Kiat pendidikan matematika di Indonesia. Jakarta: Dirjen Dikti Depdikbud.

Tarigan, Daitin. (2006). Pembelajaran matematika realistik. Jakarta: Departemen Pendidikan Nasional.

Watson, A. (2007). The nature of participation afforded by tasks, questions and prompts in mathematics classroom. Res Math Educ, 9(1), 111-126.

Watson, A. \& Mason, J. (2005). Mathematics as a constructive activity: Generating examples, Mahwah: Lawrence Erlbaum Associates. 
Lisa Ramadhani, Rahmah Johar, Bansu Irianto Ansari: Kemampuan Komunikasi Matematis ditinjau dari Keterlibatan Siswa melalui Pendekatan Realistic Mathematics Education (RME)

Wijaya, A. (2012). Pendidikan matematika realistic suatu alternative pendekatan pembelajaran matematika. Yogyakarta: Graha Ilmu.

Yackel, E., Cobb, P., \& Wood, T. (1991). Small-group interactions as a source of learning opportunities in second-grade mathematics. Journal for research in mathematics education, 22(5), 390-408.

Yuhaniz, M., Samsudin, N.S., Ismail, I., \& Zaki, M.Z.M. (2018). student engagement, collaboration and critical thinking through a board game module in an architecture history class. IDEALOGY, 3(2), 215-223.

Zakaria, E. \& Syamaun, M. (2017). The effect of realistic mathematics education approach on students' achievement and attitudes toward mathematics. Jurnal of Mathematics Education Trends and Research, 1, 32-40.

Afgani, J.D. \& Sutawidjaja, A. (2011). Materi pokok pembelajaran matematika. Jakarta: Universitas Terbuka.

Umar, W. (2012). Membangun kemampuan komunikasi matematis dalam pembelajaran matematika. Infinity Jurnal Ilmiah Program Studi Matematika STKIP Siliwangi Bandung, 1(1), 1-9.

Trowler V. (2010). Student engagement literature review. The Higher Education Academic. Lancaster University: Department of Educational Research.

Newman, M. J. (2005). Problem-based learning: An introduction and overview of the key features of the approach. London: UTPress.

Sardiman. (2006). Interaksi dan motivasi belajar-mengajar. Jakarta: Raja Grafindo Persada.

Willms, J. D. (2003). Students engagement at school: A sense of belonging and participation result from PISA 2000. Organisation for Economic Cooperation and Development. 